\title{
Anestesi ved åpen hjertekirurgi hos voksne
}

\author{
Sammendrag \\ Bakgrunn. Om lag 5000 voksne hjerte- \\ opereres i Norge hvert år, de fleste \\ med bruk av hjerte-lunge-maskin. \\ Hensikten med denne artikkelen er \\ å peke på spesielle forhold ved anes- \\ tesi til disse pasientene.
}

Materiale og metode. Artikkelen er basert på et ikke-systematisk litteratursøk i PubMed og egne kliniske og forskningsbaserte erfaringer.

Resultater. Ved åpen hjertekirurgi i Norge benyttes alltid generell anestesi. En del av pasientene har så svekket hjertefunksjon at hjertet må støttes med inotrope medikamenter eller mekaniske innretninger. Pasientene får heparin under inngrepet, og i tillegg får mange preoperativ behandling med medikamenter som innvirker på hemostasen. Dette gir risiko for per- og postoperativ blødning. Hjernen er utsatt fordi hjerte-lunge-maskinen gir ufysiologisk blodstrøm, og fordi luft eller faste partikler kan embolisere fra hjertet eller aorta under inngrepet. Postoperativ nyresvikt er en alvorlig komplikasjon med høy mortalitet. Noen anestesimidler har sannsynligvis direkte kardioprotektiv effekt. Det er holdepunkter for at nøye postoperativ blodsukkerkontroll reduserer morbiditet og mortalitet, selv om det ikke er enighet om hvilket blodsukkernivå som skal tilstrebes.

Fortolkning. Flere organsystemer blir påvirket ved hjertekirurgi. Ved siden av å sørge for god og smertefri søvn og gode arbeidsforhold for kirurgene, er utfordringen ved anestesi til disse pasientene å medvirke til best mulig organbeskyttelse.

\section{Terje Veel}

terje.veel@usa.net

Anestesiavdelingen

Feiringklinikken

2093 Feiring

\section{Jan Fredrik Bugge}

Anestesiavdelingen

Oslo universitetssykehus, Rikshospitalet

\section{Knut Arvid Kirkebøen}

Anestesiavdelingen

Oslo universitetssykehus, Ullevål

og

Fakultetsdivisjon Ullevål universitetssykehus Universitetet i Oslo

\section{Hilde Pleym}

Klinikk for hjerte- og lungekirurgi

St. Olavs hospital

og

Institutt for sirkulasjon og billeddiagnostikk Norges teknisk-naturvitenskapelige universitet

Med åpen hjertekirurgi menes kirurgi ved hjelp av hjerte-lunge-maskin. Om lag $70 \%$ er koronarkirurgi, og om lag $20 \%$ er operasjoner på hjerteklaffene. De resterende er blant annet operasjoner for medfødte hjertesykdommer og torakale aneurismer. En del inngrep for medfødte hjertesykdommer gjøres uten hjerte-lunge-maskin. Det samme gjelder for koronarkirurgi, selv om dette ikke er særlig vanlig i Norge. Tema for artikkelen er å belyse forhold ved åpen hjertekirurgi til voksne.

\section{Materiale og metode}

Innholdet $\mathrm{i}$ artikkelen bygger på forfatternes egne kliniske og forskningsmessige erfaringer, supplert med ikke-systematisk litteratursøk i PubMed. Påstander er forsøkt begrunnet med litteraturhenvisninger, men dessverre kan ikke alt $i$ vårt fag dokumenteres med store kliniske studier. Flere valg gjøres etter erfaring, opplæring, behandlingstradisjon og diskusjoner med kolleger.

\section{Anestesi og monitorering}

Ramme 1 angir vanlig brukte anestesimidler ved hjertekirurgi. Ved ukomplisert koronareller klaffekirurgi våkner pasienten som regel opp på postoperativ avdeling et par timer etter at kirurgi er avsluttet. Opplevelse av å være våken under et kirurgisk inngrep (awareness) er en komplikasjon som man tidligere anså at forekom hyppigere ved hjerteoperasjoner enn ved annen kirurgi. I nyere litteratur er det vanskelig å finne holdepunkter for dette (1-5).
Til en ukomplisert hjerteoperasjon vil standard monitorering være: EKG, pulsoksymetri, invasivt arterierykk, sentralt venetrykk, endetidal $\mathrm{pCO}_{2}$, endetidal inhalasjonsgass og kroppstemperatur. Generell bruk av pulmonalt arteriekateter er ikke vanlig, da nytten ikke er dokumentert (6-9). Transøsofageal ekkokardiografi brukes i økende grad for å vurdere volumforhold, systolisk og diastolisk venstre ventrikkelfunksjon, anatomiske forhold som klaffepatologi og tromber samt for å vurdere resultatet av operasjonen. Det siste betyr at eventuelle paravalvulære lekkasjer etter innsetting av klaffeproteser samt mindre vellykkede resultater av klaffeplastikker kan diagnostiseres umiddelbart og dermed korrigeres i samme operasjon.

\section{Postoperativ smertebehandling}

Standard smertebehandling er en kombinasjon av et opioid og paracetamol. På grunn av opioidenes bivirkningsprofil, med blant annet kløe, kvalme, urinretensjon, respirasjonsdepresjon og søvnighet, har man forsøkt å finne alternativer. Konvensjonelle ikke-steroide antiinflammatoriske midler (NSAID-preparater) har bivirkninger i form av blødning, ulcus pepticum og mulig nedsatt sårtilheling og kan derfor på langt nær brukes hos alle pasienter. De øker også risikoen for å utvikle nyresvikt, og da spesielt hos dem som har nedsatt nyrefunksjon fra før. Dette gjelder også selektive COX-2hemmere som imidlertid har vist seg uaktuelle å bruke pga. fare for tromboembolier samt risiko for nedsatt sårtilheling. Kortikosteroider har vist seg ikke å ha effekt i lave doser (10), men ut fra erfaringer ved annen kirurgi kan det forventes effekt ved større doser.

Bruk av torakal epiduralbedøvelse er omdiskutert ved hjertekirurgi. I en metaanalyse

\section{Hovedbudskap}

- Anestesi ved hjertekirurgi har samme krav til sikker $\varsigma \varnothing v n$, smertelindring og amnesi som annen anestesi

- Hjertekirurgi er vanlig og ikke uten risiko

- Mange organsystemer er utsatt for komplikasjoner

- Enkelte anestesimidler virker i seg selv organbeskyttende 
er det vist bedret postoperativ smertekontroll, bedret lungefunksjon, færre arytmier, men ikke effekt på mortalitet og forekomst av hjerteinfarkt $(11,12)$. Den gode effekten på smertekontroll må veies opp mot faren for epiduralt hematom. Det er rapportert kun et fåtall epidurale hematomer $\mathrm{i}$ forbindelse med hjertekirurgi. Fordi pasientene er utsatt for intensiv antikoagulasjon under hjertelunge-maskin, og til dels også både før og etter operasjonen, benytter ingen norske klinikker seg av torakal epiduralbedøvelse.

\section{Blodsukkerkontroll}

Diabetespasienter som hjerteopereres har økt risiko for død, iskemisk hjerneslag, sårinfeksjoner og forlenget sykehusopphold (13). Ved å holde blodsukker under $8 \mathrm{mmol} /$ 1 perioperativt og $\mathrm{i}$ tre døgn postoperativt kunne disse komplikasjonene reduseres (14). I 2001 fant van den Berghe og medarbeidere at også pasienter som ikke har diabetes bør holdes normoglykemiske postoperativt (15). Gruppen som ble holdt normoglykemisk (blodsukker 4,4-6,1 mmol/l) med intensiv insulinbehandling hadde lavere dødelighet, forekomst av nyresvikt, polynevropati og infeksjoner samt kortere sykehusopphold sammenliknet med en kontrollgruppe der man ikke startet behandling før blodsukkeret var 11,9 mmol/1. Denne ene studien, som hovedsakelig inkluderte hjertekirurgiske og karkirurgiske pasienter, førte til et bemerkelsesverdig skifte $\mathrm{i}$ behandlingsstrategi. Etter hvert har det imidlertid vist seg vanskelig å reprodusere disse funnene. En studie fra Australia og New Zealand publisert i 2009 viste at hos intensivpasienter der blodsukkeret ble holdt på 4,5-6 $\mathrm{mmol} / \mathrm{l}$ postoperativt, var mortaliteten høyere enn om blodsukkeret ble holdt på et noe høyere nivå, men under 10 mmol/l (16). Hypoglykemi er ikke uvanlig ved aggressiv blodsukkertitrering (17). Omfanget av mulig skadelig effekt av hypoglykemi i denne sammenheng er ikke avklart. To studier ble således stoppet i 2008 pga. økt forekomst av hypoglykemi $(18,19)$. Også nytten av et strikt blodsukkerregime perioperativt er omdiskutert. Et materiale fra Mayo-klinikkken fra 2007 viste at perioperativ normoglykemi (blodsukker 4,4-5,6 mmol/l) ikke reduserte mortalitet eller morbiditet, men tvert imot økte insidensen av slag (20). Vi mener det er rimelig å hevde at nøye postoperativ blodsukkerkontroll reduserer mortalitet og morbiditet, men at det ikke er avklart på hvilket blodsukkernivå behandlingsmålet skal være.

\section{Postoperativ blødning}

$2-5 \%$ av alle hjerteopererte pasienter reopereres i løpet av de første timene postoperativt på grunn av blødning. Reoperasjon er både en risikofaktor for utvikling av alvorlige komplikasjoner som nyresvikt, lungesvikt, sepsis og arytmier og en uavhengig prediktor for død $(21,22)$. I tillegg blør så mange som $20 \%$ av pasientene mer enn det som kan betraktes som normalt, men uten at disse trenger ytterligere kirurgi (23). Blødningen kan ha en åpenbar og kirurgisk korrigerbar årsak, eller den kan skyldes svekket hemostasefunksjon $(22,23)$.

Årsaker til nedsatt hemostase er knyttet til bruken av hjerte-lunge-maskin og skyldes i hovedsak en trombocyttdysfunksjon, men også forandringer i koagulasjonssystemet med forbruk av koagulasjonsfaktorer og økt fibrinolyse (23). I tillegg vil preoperativ behandling med trombocytthemmere og/ eller lavmolekylære hepariner gi økt blødningstendens postoperativt. Kombinasjonsbehandling med trombocytthemmerne klopidogrel og acetylsalisylsyre brukes nå rutinemessig hos pasienter med ustabil koronarsykdom til kort tid før operasjonen. Studier har vist at slik behandling før et hjertekirurgisk inngrep øker både blødningsrisiko, behov for blodtransfusjon og antall reoperasjoner (24).

Profylaktisk behandling med fibrinolysehemmeren traneksamsyre reduserer postoperativ blødning og transfusjonsbehov ved alle typer hjertekirurgi (25). Dersom man velger en slik behandling, gis legemidlet som en bolusdose ved inngrepets start, eventuelt etterfulgt av en intraoperativ infusjon.

Serinproteaseinhibitoren aprotinin hemmer plasmin, og profylaktisk behandling med dette legemidlet reduserer postoperativ blødning og transfusjonsbehov etter hjertekirurgi (25). Rapporter om alvorlige bivirkninger assosiert med behandling med aprotinin gjør at det i dag er usikkert om aprotinin vil ha noen plass i behandlingen av hjertekirurgiske pasienter i fremtiden (26).

Stor pågående postoperativ blødning med mistanke om svekket hemostase kan behandles med ferskfryst plasma og/eller trombocyttkonsentrat. I situasjoner med profus blødning der man ikke klarer å stoppe blødningene med kirurgi og blodkomponenter, kan man vurdere behandling med rekombinant faktor VIIa (27).

\section{Inotropi}

Av og til må inotrope medikamenter brukes for å øke hjerteminuttvolumet. Hjertefunksjonen kan være så svekket på forhånd, eller bli så svekket under kirurgi, at det nødvendiggjør en form for støtte for å komme av hjerte-lunge-maskinen og/eller stabilisere pasienten postoperativt. Noen pasienter trenger støtte også før operasjonen.

De fleste inotrope medikamenter (adrenalin, dopamin, dobutamin, efedrin, kalsium, fosfodiesterasehemmere) øker fritt intracellulært kalsium i systolen. Derved bindes mer kalsium til troponin i aktin-myosin-komplekset og kontraktil kraft øker. For å opprettholde relaksasjon i diastolen må kalsium transporteres ut av cellen eller inn i sarkoplasmatisk retikulum $i$ en energikrevende prosess. Alle disse medikamentene øker myokards energiforbruk. I behandling av

\section{Ramme 1}

\author{
Anestesimidler ved en typisk \\ hjerteanestesi \\ Tiopental: induserer søvn \\ Diazepam: induserer søvn og amnesi \\ Fentanyl: analgetikum \\ Pankuronium, cisatrakurium: muskel- \\ relaksasjon \\ Isofluran, sevofluran: inhalasjonsgas- \\ ser som vedlikeholder søvn, analgesi \\ og muskelrelaksasjon
}

både kronisk og akutt hjertesvikt har slike medikamenter vist seg å ha klart uheldige langtidseffekter i form av økt mortalitet og $ø \mathrm{kt}$ forekomst av atrieflimmer og andre arytmier (28-32). Tilvarende er vist når disse medikamentene brukes ved hjerteoperasjoner $(33,34)$.

Levosimendan er et inotropt medikament som virker annerledes enn de tradisjonelle. I stedet for å øke mengden av intracellulært kalsium, bindes kalsium sterkere til troponin (derav navnet «calcium sensitizer»). Den energikrevende kalsiumtransporten økes ikke. Levosimendan virker dessuten vasodilatatorisk, både systemisk, pulmonalt og koronart og kan ha kardioprotektiv effekt. God dokumentasjon på nytten ved hjertekirurgi savnes dog (35-37).

I tillegg til de omtalte inotrope medikamentene kan en eller annen form for mekanisk støtte være aktuelt. Mest vanlig er bruk av aortaballongpumpe. Aortaballongpumpen avlaster hjertet i systolen og øker koronar gjennomblødning i diastolen. Den er rask å sette opp og relativt lite ressurskrevende. Mer ressurskrevende er bruk av ekstrakorporal membranoksygenator og pumper som støtter venstre og/eller høyre hjertekammer.

\section{Beskyttelse av hjertet}

Kardioplegiinfusjon i aortaroten benyttes for å indusere asystoli, slik at selve kirurgien kan gjennomføres på et ikke-bevegelig hjerte.

Tidligere mente man at anestesimiddel ikke hadde betydning for resultatet ved hjertekirurgi. Ny forståelse av iskemi og reperfusjon, spesielt pre- og postkondisjonering, har endret dette synet. Prekondisjonering innebærer at hjertet tolererer iskemi bedre etter å ha vært utsatt for kortvarig iskemi. Derved reduseres infarktstørrelsen, forekomst av arytmier og kontraktil dysfunksjon (stunning). Postkondisjonering innebærer tilsvarende protektive effekter av kortvarig iskemi i tidlig reperfusjonsfase. Forståelse av de cellulære signalveiene for disse fenomenene har gitt grunnlag for farmakologisk påvirkning, og det er vist at inhalasjonsanestetika og $\delta_{1}$-opioid stimulering kan beskytte hjertet via disse mekanismene. 
Data fra både åpen hjertekirurgi og kirurgi uten hjerte-lunge-maskin indikerer at inhalasjonsanestetika har beskyttende effekt på myokard $(38,39)$. Det er også vist at ved koronarkirurgi fører inhalasjonsanestetika sammenliknet med propofol til mindre behov for inotrop støtte, kortere liggetid på intensivavdeling og kortere sykehusopphold. Effekten var størst dersom inhalasjonsanestetika ble benyttet under hele operasjonen (40). Tre metaanalyser understreker beskyttende effekt av inhalasjonsanestetika ved hjertekirurgi $(38,41,42)$. De fleste studiene er utført ved koronarkirurgi, hovedsakelig på pasienter med god venstre ventrikkelfunksjon (ejeksjonsfraksjon over $50 \%$ ). Proteksjon er også vist ved klaffekirurgi på aorta (43), men ikke ved isolert mitralklaffkirurgi (44).

Propofol er vist å ha kardioprotektive effekter eksperimentelt, ved å hemme frie oksygenradikaler (45). Kardioprotektive effekter av propofol er også påvist klinisk ved hjertekirurgi $(46,47)$. Man må imidlertid bruke høye konsentrasjoner av propofol for å oppnå dette (46).

Kun i én studie er opioiders kardioprotektive effekt undersøkt ved hjertekirurgi. Murphy og medarbeidere viste at forbehandling med morfin $40 \mathrm{mg}$, sammenliknet med fentanyl $1 \mathrm{mg}$ før aortatang ble satt på, førte til bedret diastolisk og systolisk funksjon bedømt ved ekkokardiografi (48).

Ny kunnskap om iskemi og reperfusjon har åpnet flere muligheter for nye protektive strategier. Farmakologisk modulering av cellulære mekanismer som medierer preog postkondisjonering kan være aktuelt. En annen tilnærming kan være avstandsprekondisjonering (remote preconditioning): Kortvarig iskemi $\mathrm{i}$ andre organer fører til at hjertet blir beskyttet. Et eksempel er en studie der man ved koronarkirurgi fant at tre avklemninger av en overarm i fem minutter med fem minutters reperfusjon mellom førte til redusert troponin-T-frigjøring sammenliknet med kontrollgruppen (49).

Adenosintrifosfat (ATP)-følsomme kaliumkanaler $\left(\mathrm{K}_{\text {ATP }}\right)$ er en helt sentral mediator av pre- og postkondisjonering. Pasienter som skal til hjertekirurgi bør ikke stå på sulfonylureapreparater, en gruppe perorale antidiabetika som hemmer $\mathrm{K}_{\text {ATP }}$-kanaler, de siste par dagene før og de første par dagene etter kirurgi. De bør heller ikke stå på COX2-hemmere, da disse også er vist å kunne motvirke kardioproteksjonsfenomenene. Observasjonelle studier tyder på at betablokkere ved hjertekirurgi fører til redusert mortalitet og redusert forekomst av atrieflimmer og cerebrovaskulære hendelser. Det blir anbefalt å kontinuere statinbehandling $\mathrm{i}$ forbindelse med hjertekirurgi.

\section{Beskyttelse av hjernen}

Iskemisk hjerneslag med påfølgende kognitiv dysfunksjon er ikke helt uvanlig etter hjertekirurgi $(50,51)$ (ramme 2). Risikofak- torer for nevrologiske hendelser ligger til dels hos pasienten selv, i form av høy alder, cerbrovaskulær sykdom, aterosklerose, diabetes og hypertensjon, men er også relatert til selve prosedyren. Både bruk av hjertelunge-maskin og tang på aorta gir økt embolifare. Kirurgi som medfører åpning av hjertet øker muligheten for luftembolier, og prosedyrer som må foregå i sirkulasjonsstans medfører risiko for hypoksisk hjerneskade.

Hypotermi beskytter hjernen, selv ved $1-2{ }^{\circ} \mathrm{C}$ nedkjøling. Ved langvarige prosedyrer er det vanlig å kjøle til $30-32^{\circ} \mathrm{C}$, mens det ved vanlig koronarkirurgi enten ikke kjøles i det hele tatt, eller bare 2-3 grader. Dersom inngrepet krever full sirkulasjonsstans, som for eksempel enkelte inngrep på aorta ascendens, er det vanlig å kjøle pasienten ned mot $20-25^{\circ} \mathrm{C}$. I egnede tilfeller kan det også være aktuelt med selektiv cerebral perfusjon som alternativ til full sirkulasjonsstans, og da kan behovet for kjøling reduseres noe. Cerebral hypertermi er skadelig, og det er derfor viktig å unngå dette ved oppvarming fra hypotermi. Etter vår mening bør blodet fra hjerte-lunge-maskinen ikke varmes til mer enn $37^{\circ} \mathrm{C}$ før det går inn i pasienten.

For å opprettholde adekvat oksygentransport til hjernen under bruk av hjerte-lungemaskin må blodgjennomstrømning, blodtrykk, sentralt venetrykk, hemoglobin og $\mathrm{pCO}_{2}$ kontrolleres og justeres. Tradisjonelt er disse variablene justert etter erfaring og definerte mål uten at noe måles i selve hjernen. Cerebral oksymetri er en relativt ny metode som ved hjelp av infrarødt eller laserlys måler oksygenmetningen i hjernevev. Det finnes data som tyder på at metodikken kan bidra til bedre nevrologisk utfall $(52,53)$. Etter vår oppfatning er metodikken for lite utprøvd, og resultatene ikke tilstrekkelig overbevisende til at vi kan anbefale den til rutinemessig bruk, men den bør brukes ved inngrep på torakalaorta, spesielt der antegrad cerebral perfusjon benyttes.

Hvorvidt medikamenter som tiopental og steroider beskytter hjernen spesifikt mot iskemi er omdiskutert, men brukes mange steder i form av bolusdoser rett før introduksjon av sirkulasjonsstans. Nyere medikamenter som adenosinmodulatoren acadesine har heller ikke fått gjennomslag selv etter lovende resultater i fase 3 -studier $(54,55)$.

\section{Beskyttelse av nyrene}

Akutt nyresvikt i forbindelse med hjertekirurgi er en alvorlig komplikasjon og en betydelig risikofaktor for tidlig postoperativ død (56). I større amerikanske materialer forekommer postoperativ nyresvikt som krever nyreerstattende terapi i form av dialyse eller hemofiltrasjon hos omtrent $1,5 \%$ av pasientene, stigende fra $1 \%$ etter ren koronarkirurgi til $5 \%$ for kombinasjonen koronar- og mitralklaffkirurgi (57). Dialysekrevende nyresvikt er den postoperative risikofaktoren med sterkest innflytelse på sykehusmortali-

\section{Ramme 2}

\section{Komplikasjonsfrekvens ved hjertekirurgi}

Basert på data fra alle hjerteopererte i Norge i 2007, Norsk thoraxkirurgisk forenings hjerteregister
Død innen 30 dager fra operasjonsdato: $2,3 \%$
Postoperativ nyresvikt (definert som kreatinin > 200): $2,2 \%$
Reoperasjon for postoperativ blødning: $4 \%$
Iskemisk hjerneslag: 1,5\%
Respirator $>24$ timer: $4,7 \%$
Aortaballongpumpe eller ekstrakor- poral membranoksygenering: $3 \%$
Sepsis: 0,5\%
Dyp sårinfeksjon: 0,6\%

tet, som øker fra $1-2 \%$ til $45-55 \%$ (57, 58 ). Selv et mindre fall i nyrefunksjonen $i$ form av en postoperativ stigning $\mathrm{i}$ serumkreatinin i størrelsesorden $40-50 \mu \mathrm{mol} / 1$, har en betydelig negativ effekt på overlevel$\operatorname{sen}(59)$.

\section{Nedsatt nyrefunksjon preoperativt}

En dominerende risikofaktor for å få dialysetrengende nyresvikt postoperativt er nedsatt preoperativ nyrefunksjon. Forhøyet preoperativ serum-kreatinin er en uavhengig risikofaktor for multiorgansvikt og tidlig postoperativ død $(57,58,60-62)$.

\section{Hjerte-lunge-maskin og nyreskade}

Kardiopulmonell bypass med hjerte-lungemaskin har generelt vært akseptert å kunne gi nyreskade selv hos nyrefriske. Mazzarella og medarbeidere målte basal og stimulert (proteinbelastning) glomerulær filtrasjonshastighet før og etter hjertekirurgi hos pasienter med normal nyrefunksjon. De fant ingen endring $\mathrm{i}$ basal filtrasjon, men evnen til å kunne øke filtrasjonshastigheten etter proteinbelastning gikk tapt $i$ en uke etter kirurgien (63). Mulige mekanismer for nyreskade indusert av hjerte-lunge-maskin er ikke godt kartlagt, men har vært relatert til hypoperfusjon, aktivering av kaskadesystemer som komplement og koagulasjon samt immunrespons som følge av kontakt mellom blod og kunstige overflater i hjerte-lungemaskinkretsen $(64,65)$.

Det har vært gjort mange forskjellige tilnærminger for å beskytte nyrene under hjerte-lunge-maskinkjøring. Perioperativ administrasjon av en rekke medikamenter som kalsiumantagonister, diuretika, dopamin og ACE-hemmere har vært prøvd som forbyggende behandling både hos pasienter med normal og med nedsatt nyrefunksjon. Resul- 
tatene er motstridende. En Cochrane-oversikt fra 2008 konkluderer med at det ikke er noen perioperativ medikamentell intervensjon som effektivt beskytter nyrefunksjonen (66).

I en norsk undersøkelse publisert i 2008 fant man ingen fall i nyrefunksjonen etter hjertekirurgi hos 20 pasienter med betydelig nedsatt preoperativ nyrefunksjon (67). I denne undersøkelsen ble det lagt vekt på å holde blodtrykket $\geq 50 \mathrm{~mm} \mathrm{Hg}$ under hjertelunge-maskinkjøring samt at hjerte-lungemaskinkretsen hadde en overflate dekket med et biokompatibelt materiale. Disse funnene er senere bekreftet av andre (68). Tidligere antakelser om at hjerte-lunge-maskinen i seg selv induserer nyreskade kan ikke bekreftes i nyere undersøkelser, og vi konkluderer med at moderne teknikk for hjertelunge-maskinkjøring er i stand til å bevare nyrefunksjonen selv hos pasienter med betydelig nedsatt nyrefunksjon.

\section{Konklusjon}

Hjertekirurgi er vanlig og utføres ved fem sentre i landet. Det er en ikke helt ubetydelig risiko for komplikasjoner forbundet med inngrepet. Flere organsystemer kan bli affisert. Denne type kirurgi er ressurskrevende og utføres på til dels svært syke pasienter. Nøye per- og postoperativ overvåking og rask iverksetting av adekvate tiltak er nødvendig for å sikre gode behandlingsmessige resultater.

Oppgitte interessekonflikter: Terje Veel har gjennom sitt arbeid ved Feiringklinikken deltatt $i$ en multisenterstudie i 2003 i regi av Pfiizer (sikkerhet og effekt av COX-2-hemmerne parekoksib og valdekoksib ble undersøkt). Knut Arvid Kirkebøen har de siste fem årene mottatt støtte fra Abbott og Orion Pharma for foredrag. Jan Bugge sitter «advisory board» for levosimendan (Simdax) for Orion Pharma. Hilde Pleym har ingen oppgitte interessekonflikter.

\section{Litteratur}

1. Errando CL, Sigl JC, Robles M et al. Awareness with recall during general anaesthesia: a prospective observational evaluation of 4001 patients. Br J Anaesth 2008; 101: 178-85.

2. Ghoneim MM. Incidence of and risk factors for awareness during anaesthesia. Best Pract Res Clin Anaesthesiol 2007; 21: 327-43.

3. Rungreungvanich M, Thienthong S, Charuluxananan $\mathrm{S}$ et al. Predictors of intra-operative recall of awareness: Thai Anesthesia Incidents Study (THA Study): a case-control study. J Med Assoc Thai 2007; 90: $1551-7$.

4. Sebel PS, Bowdle TA, Ghoneim MM et al. The incidence of awareness during anesthesia: a multicenter United States study. Anesth Analg 2004; 99 833-9.

5. Shi $X$, Liu XY, Wang $W$ et al. Awareness with recall during general anesthesia: analysis of 2015 cases. Zhonghua Yi Xue Za Zhi 2006; 86: 2324-7.

6. Sandham JD, Hull RD, Brant RF et al. A random ized, controlled trial of the use of pulmonaryartery catheters in high-risk surgical patients N Engl J Med 2003; 348: 5-14.

7. Polanczyk CA, Rohde LE, Goldman L et al. Right heart catheterization and cardiac complications in patients undergoing noncardiac surgery: an observational study. JAMA 2001; 286: 309-14.
8. Richard C, Warszawski J, Anguel N et al. Early use of the pulmonary artery catheter and outcomes in patients with shock and acute respiratory distress syndrome: a randomized controlled trial. JAMA 2003: 290: 2713-20.

9. Polonen P, Ruokonen E, Hippelainen M et al. A prospective, randomized study of goal-oriented hemodynamic therapy in cardiac surgical patients. Anesth Analg 2000; 90: 1052-9.

10. Halvorsen P. Raeder J, White PF et al. The effect of dexamethasone on side effects after coronary revascularization procedures. Anesth Analg 2003 96: 1578-83.

11. Liu SS, Block BM, Wu CL. Effects of perioperative central neuraxial analgesia on outcome after coronary artery bypass surgery: a meta-analysis. Anesthesiology 2004; 101: 153-61.

12. Chaney MA. Intrathecal and epidural anesthesia and analgesia for cardiac surgery. Anesth Analg 2006; 102: 45-64.

13. Brown JR, Edwards FH, O'Connor GT et al. The diabetic disadvantage: historical outcomes measures in diabetic patients undergoing cardiac surgery - the pre-intravenous insulin era. Semin Thorac Cardiovasc Surg 2006; 18: $281-8$.

14. Furnary AP, Wu Y, Bookin SO. Effect of hyperglyce mia and continuous intravenous insulin infusions on outcomes of cardiac surgical procedures: the Portland Diabetic Project. Endocr Pract 2004; 10 (suppl 2): 21-33.

15. Van den Berghe G, Wouters P, Weekers F et al. Intensive insulin therapy in the critically ill patients. N Engl J Med 2001; 345: 1359-67.

16. Finfer S, Chittock DR, Su SY et al. Intensive versus conventional glucose control in critically ill patients. N Engl J Med 2009; 360: 1283-97.

17. Alm-Kruse K, Bull E, Laake JH. Nurse-led implementation of an insulin-infusion protocol in a gen eral intensive care unit: improved glycaemic control with increased costs and risk of hypoglycaemia signals need for algorithm revision. BMC Nurs 2008; 7: 1

18. Preiser JC. Restoring normoglycaemia: not so harmless. Crit Care 2008; 12: 116.

19. Brunkhorst FM, Engel C, Bloos F et al. Intensive insulin therapy and pentastarch resuscitation in severe sepsis. N Engl J Med 2008; 358: 125-39.

20. Gandhi GY, Nuttall GA, Abel MD et al. Intensive intraoperative insulin therapy versus conventional glucose management during cardiac surgery: a randomized trial. Ann Intern Med 2007; 146 233-43.

21. Moulton MJ, Creswell LL, Mackey ME et al. Reexploration for bleeding is a risk factor for adverse outcomes after cardiac operations. J Thorac Cardiovasc Surg 1996: 111: 1037-46.

22. Sellman M, Intonti MA, Ivert T. Reoperations for bleeding after coronary artery bypass procedures during 25 years. Eur J Cardiothorac Surg 1997; 11: $521-7$.

23. Paparella D, Brister SJ, Buchanan MR. Coagulation disorders of cardiopulmonary bypass: a review. Intensive Care Med 2004; 30: 1873-81.

24. Chu MW, Wilson SR, Novick RJ et al. Does clopidogrel increase blood loss following coronary artery bypass surgery? Ann Thorac Surg 2004; 78 . $1536-41$

25. Levi M, Cromheecke ME, de Jonge E et al. Pharmacological strategies to decrease excessive blood loss in cardiac surgery: a meta-analysis of clinically relevant endpoints. Lancet 1999; 354: $1940-7$

26. Fergusson DA, Hebert PC, Mazer CD et al. A comparison of aprotinin and lysine analogues in highrisk cardiac surgery. N Engl J Med 2008; 358: 2319-31

27. Vincent JL, Rossaint R, Riou B et al. Recommendations on the use of recombinant activated factor VII as an adjunctive treatment for massive bleeding-a European perspective. Crit Care 2006; 10: R120.

28. Cuffe MS, Califf RM, Adams KF jr. et al. Short-term intravenous milrinone for acute exacerbation of chronic heart failure: a randomized controlled trial. JAMA 2002; 287: 1541-7.

29. Petersen JW, Felker GM. Inotropes in the management of acute heart failure. Crit Care Med 2008; 36: S106-11.

30. Packer M, Medina N, Yushak M. Hemodynamic and clinical limitations of long-term inotropic therapy with amrinone in patients with severe chronic heart failure. Circulation 1984; 70: 1038-47.

31. Packer M, Carver JR, Rodeheffer RJ et al. Effect of oral milrinone on mortality in severe chronic heart failure. The PROMISE Study Research Group. N Engl J Med 1991; 325: 1468-75.

32. Massie BM, Berk MR, Brozena SC et al. Can further benefit be achieved by adding flosequinan to patients with congestive heart failure who remain symptomatic on diuretic, digoxin, and an angiotensin converting enzyme inhibitor? Results of the flosequinan-ACE inhibitor trial (FACET). Cir culation 1993; 88: 492-501.

33. Fellahi JL, Parienti JJ, Hanouz JL et al. Perioperative use of dobutamine in cardiac surgery and adverse cardiac outcome: propensity-adjusted analyses. Anesthesiology 2008; 108: 979-87.

34. Mangi AA, Christison-Lagay ER, Torchiana DF et al. Gastrointestinal complications in patients undergoing heart operation: an analysis of 8709 consecutive cardiac surgical patients. Ann Surg 2005; 241: 895-901.

35. Follath F. Cleland JG, Just $\mathrm{H}$ et al. Efficacy and safety of intravenous levosimendan compared with dobutamine in severe low-output heart failure (the LIDO study): a randomised double-blind trial. Lancet 2002; 360: 196-202.

36. Moiseyev VS, Poder P. Andrejevs N et al. Safety and efficacy of a novel calcium sensitizer, levosimendan, in patients with left ventricular failure due to an acute myocardial infarction. A randomized, placebo-controlled, double-blind study (RUSSLAN). Eur Heart J 2002; 23: 1422-32.

37. Cleland JG, Freemantle N, Coletta AP et al. Clinical trials update from the American Heart Association: REPAIR-AMI, ASTAMI, JELIS, MEGA, REVIVE-II, SURVIVE, and PROACTIVE. Eur J Heart Fail 2006: 8: 105-10

38. Landoni G, Biondi-Zoccai GG, Zangrillo A et al. Desflurane and sevoflurane in cardiac surgery: a meta-analysis of randomized clinical trials. J Cardiothorac Vasc Anesth 2007: 21: 502-11.

39. De Hert SG, Cromheecke S, ten Broecke PW et al. Effects of propofol, desflurane, and sevoflurane on recovery of myocardial function after coronary surgery in elderly high-risk patients. Anesthesiology 2003; 99: 314-23

40. De Hert SGM, Van der Linden PJ, Cromheecke S et al. Cardioprotective properties of sevoflurane in patients undergoing coronary surgery with cardiopulmonary bypass are related to the modalities of its administration. Anesthesiology 2004; 101: $299-310$

41. Symons JA, Myles PS. Myocardial protection with volatile anaesthetic agents during coronary artery bypass surgery: a meta-analysis. $\mathrm{Br} \mathrm{J}$ Anaesth 2006; 97: 127-36.

42. Yu CH, Beattie WS. The effects of volatile anesthe tics on cardiac ischemic complications and mortality in CABG: a meta-analysis. Can J Anaesth 2006; 53: $906-18$

43. Cromheecke S, Pepermans V, Hendrickx E et al. Cardioprotective properties of sevoflurane in patients undergoing aortic valve replacement with cardiopulmonary bypass. Anesth Analg 2006; 103. 289-96.

44. Landoni G, Calabro MG, Marchetti $C$ et al. Desflurane versus propofol in patients undergoing mitral valve surgery. J Cardiothorac Vasc Anesth 2007; 21: $672-7$

45. Xia Z, Godin DV, Ansley DM. Application of highdose propofol during ischemia improves postischemic function of rat hearts: effects on tissue antioxidant capacity. Can J Physiol Pharmacol 2004; 82: 919-26.

46. Xia Z, Huang Z, Ansley DM. Large-dose propofol during cardiopulmonary bypass decreases biochemical markers of myocardial injury in coronary surgery patients: a comparison with isoflurane. Anesth Analg 2006; 103: 527-32.

47. Jakobsen CJ, Berg H, Hindsholm KB et al. The influence of propofol versus sevoflurane anesthesia on outcome in 10535 cardiac surgical procedures. J Cardiothorac Vasc Anesth 2007: 21. 664-71.

48. Murphy GS, Szokol JW, Marymont JH et al. Opioids and cardioprotection: the impact of morphine and fentanyl on recovery of ventricular function after cardiopulmonary bypass. J Cardiothorac Vasc Anesth 2006; 20: 493-502. 
49. Hausenloy DJ, Mwamure PK, Venugopal V et al. Effect of remote ischaemic preconditioning on myocardial injury in patients undergoing coronary artery bypass graft surgery: a randomised controlled trial. Lancet 2007; 370: 575-9.

50. Hogue CWJ, Barzilai BM, Pieper KSM et al. Sex differences in neurological outcomes and mortality after cardiac surgery: a Society of Thoracic Surgery National Database Report. Circulation 2001; 103: $2133-7$.

51. Goto TM, Baba TM, Ito AM et al. Gender differences in stroke risk among the elderly after coronary artery surgery. Anesth Analg 2007; 104: 1016-22.

52. Murkin JM, Adams SJ, Novick RJ et al. Monitoring brain oxygen saturation during coronary bypass surgery: a randomized, prospective study. Anesth Analg 2007; 104: 51-8.

53. Casati A, Fanelli G, Pietropaoli P et al. Continuous monitoring of cerebral oxygen saturation in elderly patients undergoing major abdominal surgery minimizes brain exposure to potential hypoxia. Anesth Analg 2005; 101: 740-7.

54. Mangano DT, Miao Y, Tudor IC et al. Post-reperfusion myocardial infarction: long-term survival improvement using adenosine regulation with acadesine. J Am Coll Cardiol 2006; 48: 206-14.

55. Mangano DT. Effects of acadesine on myocardial infarction, stroke, and death following surgery. A meta-analysis of the 5 international randomized trials. The Multicenter Study of Perioperative Ischemia (McSPI) Research Group. JAMA 1997; 277: 325-32.

56. Chertow GM, Levy EM, Hammermeister KE et al. Independent association between acute renal failure and mortality following cardiac surgery. Am J Med 1998; 104: 343-8.

57. Mehta RH, Grab JD, O'Brien SM et al. Bedside tool for predicting the risk of postoperative dialysis in patients undergoing cardiac surgery. Circulation 2006; 114: 2208-16.

58. Hein OV, Birnbaum J, Wernecke KD et al. Threeyear survival after four major post-cardiac operative complications. Crit Care Med 2006; 34: 2729-37.

59. Lassnigg A, Schmidlin D, Mouhieddine M et al. Minimal changes of serum creatinine predict prognosis in patients after cardiothoracic surgery: a prospective cohort study. J Am Soc Nephrol 2004; 15: 1597-605.

60. Wang F, Dupuis JY, Nathan $\mathrm{H}$ et al. An analysis of the association between preoperative renal dysfunction and outcome in cardiac surgery: estimated creatinine clearance or plasma creatinine level as measures of renal function. Chest 2003; 124: $1852-62$

61. Brown JR, Cochran RP, Dacey LJ et al. Perioperative increases in serum creatinine are predictive of increased 90-day mortality after coronary artery bypass graft surgery. Circulation 2006; 114 (suppl 1): $1409-13$

62. Weerasinghe A, Hornick P. Smith P et al. Coronary artery bypass grafting in non-dialysis-dependent mild-to-moderate renal dysfunction. J Thorac Cardiovasc Surg 2001; 121: 1083-9

63. Mazzarella V, Gallucci MT, Tozzo C et al. Renal function in patients undergoing cardiopulmonary bypass operations. J Thorac Cardiovasc Surg 1992; 104: $1625-7$.

64. Levy JH, Tanaka KA. Inflammatory response to cardiopulmonary bypass. Ann Thorac Surg 2003; 75: $5715-20$

65. Asimakopoulos G. Systemic inflammation and cardiac surgery: an update. Perfusion 2001; 16: 353-60

66. Zacharias M, Conlon NP. Herbison GP et al. Interventions for protecting renal function in the perioperative period. Cochrane Database Syst Rev 2008; nr.4: CD003590.

67. Witczak BJ, Hartmann A, Geiran OR et al. Renal function after cardiopulmonary bypass surgery in patients with impaired renal function. A randomized study of the effect of nifedipine. Eur J Anaesthesiol 2008; 25: 319-25.

68. Loef BG, Henning RH, Navis $G$ et al. Changes in glomerular filtration rate after cardiac surgery with cardiopulmonary bypass in patients with mild preoperative renal dysfunction. Br J Anaesth 2008; 100: $759-64$. 